\title{
Turkish Dolphin Fisheries
}

\author{
Fikret Berkes
}

In 1966 the USSR and Bulgarian governments prohibited dolphin fishing in the Black Sea after a population crash. Turkey, however, continues to catch dolphins (mainly for the oil) and is the only nation in the world to have such a fishery. Little is known about the stocks of the three dolphin species involved, and the author urges the importance of accurate catch records.

Turkey is the only nation in the world reporting a major catch of dolphins, according to FAO statistics. The catch comes from the Black Sea where all other states have stopped dolphin fishing, ${ }^{7}$ but little information is readily available about it. This report brings together some new data and information not available in English, and points out the major gaps in knowledge affecting the conservation of these Black Sea stocks.

The three species involved are the common and bottle-nosed dolphins Delphinus delphis and Tursiops truncatus and the common or harbour porpoise Phocoena phocoena. ${ }^{7}$ Their Turkish names are Karadeniz yunus baligi, Siyah yunus baligi, and Azak yunus baligi respectively. ${ }^{8}$ The Black Sea supports, or used to support, large dolphin populations; Caspers quotes an estimated total of one million, presumably of all three species. ${ }^{3}$ As one of the commonest groups of top predators they have an important role in the Black Sea ecosystem where the energy flow is from the plankton to plankton-eating fish (mainly sprats and anchovy) to dolphins. ${ }^{3}$

Casper's food-chain reconstruction probably refers mainly to Delphinus which, according to Tomilin, ${ }^{9}$ eats sprats in summer and anchovy in winter. The Black Sea Delphinus has an average weight of $43-59 \mathrm{~kg}$, is a pelagic (open water) species and was 200 times more numerous than Tursiops in the USSR fishery. ${ }^{9}$ The larger Tursiops, which feeds on neritic (coastal) bottom fauna, averages $2.25 \mathrm{~m}$ in body length, compared with $1.85 \mathrm{~m}$ for a Delphinus weighing $60 \mathrm{~kg} .{ }^{9}$ The third species, .Phocoena, averaging $30 \mathrm{~kg},{ }^{9}$ became increasingly important in the Black Sea fishery until by 1964-66 it comprised the major catch off the USSR Caucasus coast. ${ }^{7}$

Mitchell classifies the conservation status of all three species as "Indeterminate'. There is some question, however, on their taxonomic status. According to Caspers the Black Sea has been geographically isolated only for relatively short periods so that even subspecific recognition of the dolphin populations is questionable, but Tomilin gives subspecific recognition to each population: D.d. ponticus, T.t. ponticus and P.p. relicta, backed up by many data on anatomical differences between these and other populations. ${ }^{9}$ For at least one of the species, there is potential for gene exchange with subpopulations outside the Black Sea. The Mediterranean $D$. delphis has a spring migration through the Marmara Sea and the Bosphorus into the Black Sea and out again in the autumn. ${ }^{8}$

\section{Turkish Fishery}

Dolphins are harvested by Turkey mainly for the oil, the rest of the carcass going for fish meal to the Trabzon reduction plant in the eastern Black Sea. 
Table 1. World catch of 'dolphins' (excluding small whales) in thousand metric tons.

$\begin{array}{llllllllll} & 1965 & 1966 & 1967 & 1968 & 1969 & 1970 & 1971 & 1972 & 1973 \\ \text { Turkey } & 1 \cdot 3 & 5 \cdot 9 & 0 \cdot 2 & 2 \cdot 2 & 8 \cdot 3 & 3 \cdot 4 & 4 \cdot 4 & 4 \cdot 4 \mathrm{e} & 4.4 \mathrm{e} \\ \text { Other } & 0 \cdot 2 \mathrm{e} & 0 \cdot 1 \mathrm{e} & 0 \cdot 2 \mathrm{e} & 0 \cdot 1 \mathrm{e} & 0 \cdot 4 \mathrm{e} & 0 \cdot 3 \mathrm{e} & 0.2 \mathrm{e} & - & -\end{array}$

The symbol 'e' denotes an estimate by FAO (FAO, 1974, p. 517).

FAO records indicate Turkey as the only nation in the world presently taking dolphins in large numbers (Table 1), but it is clear that other nations are doing so, mainly as incidental catches. ${ }^{7}$ In the early 1970 s the US alone caught (and discarded) some 200,000 to 300,000 dolphins a year in tuna nets. ${ }^{5}$ For comparison, the 1971 Turkish catch of 4400 tons, if the average weight was 50 $\mathrm{kg}$, may represent 88,000 dolphins. Detailed marine resource harvest figures are available for the years 1970 and 1971. Table 2 shows that Turkey's dolphin catch tends to be concentrated in relatively few areas; it also gives the marine turtle catch for comparison. In 1969, 90 per cent of the 8346 tons caught came from two centres in the eastern Black Sea, Ordu, by far the largest, and Rize, the second largest. ${ }^{10}$

\section{Catching Methods}

Purse-seining and shooting are the two major capture methods in Turkish waters. ${ }^{8}$ Purse-seines are $800-1500 \mathrm{~m}$ long and $100 \mathrm{~m}$ deep, with an $8-12 \mathrm{~cm}$ mesh netting. Shooting is carried out from $20-150 \mathrm{hp}$ vessels usually with a crew of seven. Sharp-shooters, firing from within $60-70 \mathrm{~m}$, try to hit the dolphin on the light-coloured underside; if the bullet strikes the dorsal region, the animal will only be wounded and difficult to capture. Citing S. Uner, Sarikaya notes that shooting does not work well with Tursiops which sinks before it can be retrieved. According to Slastanenko, shooting is a poor method because it is most effective in catching young and inexperienced animals and also results in a 50 per cent loss by sinking, especially in summer. ${ }^{8}$ An unpublished report of the Hydrobiological Research Institute of the University of Istanbul concluded that the dolphins were overfished, but their recommendation that shooting be discontinued ${ }^{8}$ appears to have run into a political block by some groups of dolphin fishermen. The Aquatic Resources Act of 1973 (1380 Sayili Su Ürühleri Kanunu, 1973) stipulates that dolphin hunters be given free guns and bullets. In practice, they have been receiving guns free, and bullets at a government-subsidised price. ${ }^{8}$ The only restriction on the fishery is a seasonal prohibition, June 10 to September 30 , in territorial waters; this is the breeding season, which is summer for all three species. The restriction can probably be effectively enforced, for in summer dolphins have a low fat content and would bring relatively little economic return to the fishermen. Interviews with experienced fishermen disclosed that the low fat content of the Aegean and the Mediterranean stocks compared with those of the Black Sea is probably the main reason they are not hunted in these seas.

In 1977 the closed season for dolphin fishing was extended to April 1October 1, and the price of bullets supplied to dolphin hunters was increased (S. Sarikaya, pers. comm., 24/2/77). This may be a step towards the eventual prohibition of shooting dolphins. 


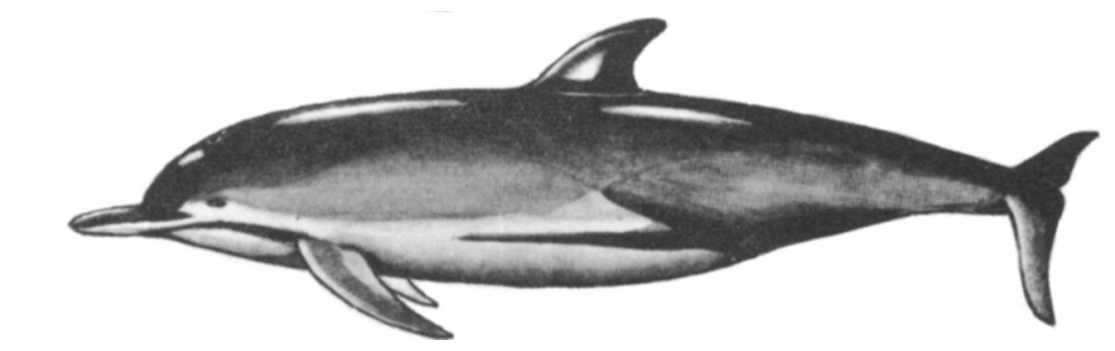

COMMON DOLPHIN

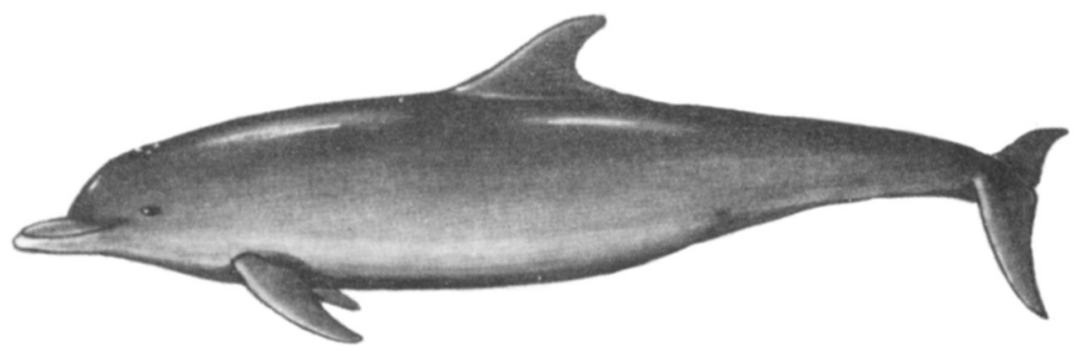

BOTTLENOSED DOLPHIN

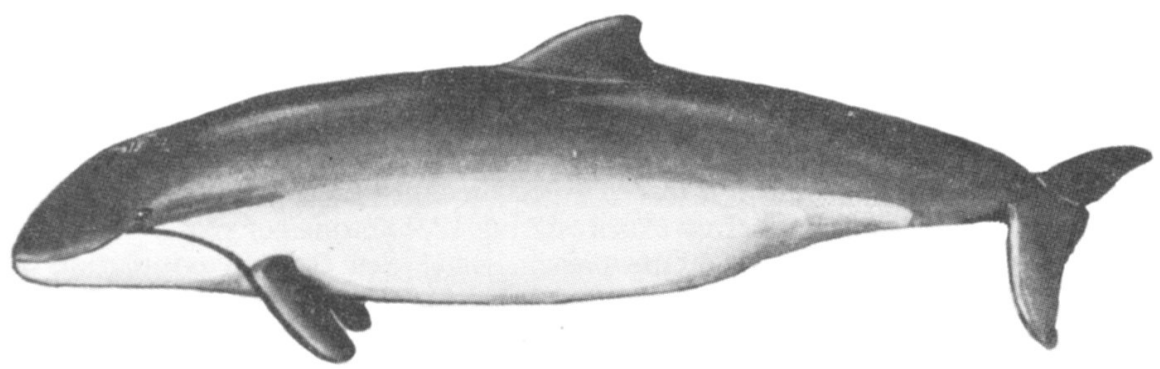

HARBOUR PORPOISE

\section{Dolphin-Fisherman Relationships}

Interviews with fishermen in 1976 and 1977, during a Mediterranean monk seal Monachus monachus study on Turkish coasts, produced some incidental information on dolphins. ${ }^{2}$ Aegean and Mediterranean fishermen report dolphins to be common, and complain about their damage to nets, but they do not hunt them, believing it is sinful (günah) to do so. However, this belief seems to have been abandoned by some Black Sea fisherman in the face of economic considerations. Many fishermen said that dolphins were useful both in keeping away sharks and dogfish (probably mainly Squalus acanthias) and in driving fish schools in to coastal areas and the fishermen's nets. ${ }^{8}$ Coastal fish trap and weir opera tors used to complain about dolphins damaging their gear; now the same fishermen complain that there are not enough dolphins to drive the fish into their weirs! 
Table 2. Catch of dolphins and marine turtles in Turkish waters, in thousand $\mathrm{kg}$ or tons

$\begin{array}{lcccccc} & \text { Eastern } & \text { Western } & \text { Marmara } & & & \\ & \text { Black Sea } & \text { Black Sea } & \text { Sea } & \text { Aegean } & \text { Mediterranean } & \text { Total } \\ \begin{array}{l}\text { Dolphins } \\ (1970)\end{array} & 3,424 & - & 1.5 & 0.5 & - & 3,426 \\ \begin{array}{l}\text { Turtles } \\ (1970)\end{array} & - & - & 2 & 4 & 12 \cdot 1 & 18.2 \\ \begin{array}{l}\text { Dolphins } \\ (1971)\end{array} & 3,367 & 1,078 & - & - & - & 4,444 \\ \begin{array}{l}\text { Turtles } \\ (1971)\end{array} & - & - & 0.8 & 0.4 & 13.6 & 14.8\end{array}$

(Turkish State Institute of Statistics, 1974, pp. 10-11).

\section{Prospects for the Fishery}

Following a severe decline in 1964-66 in the USSR and Bulgarian Black Sea dolphin fisheries, both governments prohibited the killing of dolphins; ${ }^{4,7}$ so, presumably, did Romania, the other member state of the International Convention on Marine Resources of the Black Sea (MCBSF) ${ }^{6}$ Turkey, which is not an MCBSF member, may be said to have benefited from the ban. In 1938 the total Black Sea catch showed a maximum of 7290 tons, probably representing 147,000 animals, ${ }^{4,7}$ (which can be compared with the figure in Table 2). However, this may have been an underestimate, as Caspers refers to a (maximum?) total yearly catch of 200,000 dolphins. ${ }^{3}$ The total dolphin biomass in the Black Sea was estimated at 50,000 tonnes (equivalent of a million individuals at $50 \mathrm{~kg}$ each), and their annual production at 17,000 tonnes or 35 per cent of the biomass. ${ }^{3}$ A yield level of 35 per cent of the standing stock appears high in retrospect because the fishery collapsed, at least on the USSR side, before ever reaching 17,000 tons per year.*

Information on the size of the present Black Sea dolphin population is incomplete. In 1974, a Moscow news agency reported that the number of dolphins in the Black Sea (presumably all species) had trebled to 800,000 since the ban. ${ }^{1}$ If this is accurate, then the fairly large Turkish fishery does not seem to be preventing the recovery of dolphin stocks. But sooner or later the other Black Sea states will want their share, so that accurate catch statistics are important. In addition to gross population estimates, the catch effort of the Turkish fishery and the catch per unit of effort, which is probably the single best indicator of overfishing, ${ }^{6}$ should be monitored. As a minimum, information is needed on the species composition of the catch, for in a multispecies fishery one species may be efficiently exploited while another, taken as an incidental catch, may be fished out of economic and eventually biological existence. ${ }^{7}$

* A possible explanation for miscalculation of yield levels is that the Russian literature from the 1950 s assumed that Delphinus reached reproductive maturity at 2 years of age. The D. delphis age of maturity is still not known, but, on the basis of information on closely related species, it is almost certainly greater than two years (D. E. Sergeant, pers. comm.). The age of maturity, of course, has an important bearing on the rate at which a population can reproduce itself and support a fishery. 


\section{Acknowledgments}

It is a pleasure to acknowledge the help and support of Dr D. E. Sergeant of Environment Canada, the International Union for Conservation of Nature and Natural Resources (IUCN), and Mr Süleyman Sarikaya of the Division of Marine Fisheries, Turkish Ministry of Food and Agriculture.

\section{References}

1. ANON. 1974. Dolphin census. Mar. Poll. Bull., 5(2), 19.

2. BERKES, F, 1976. Monk seals on the southwest coasts of Turkey. FAO Scientific Consultation on Marine Mammals, Bergen, Norway.

3. CASPERS, H. 1957. Black Sea and the Sea of Azov. Hedgpeth, J.W. (ed.) Treatise on Marine Ecology and Paleoecology, Vol. 1, Ecology. USGS Mem. 67, 801-889.

4. DANILEVSKIY, N.N. and V.P. TYUTYÄNNIKOV 1968. Present state of Black Sea dolphin described. Rybnoye Khozyaystvo Nov. 25-27. USSR Fishing Industry and Marine Resources, no. 24, 1-6. Joint Publ. Res. Ser. No. 47, 438 Washington (cited in Mitchell 1975).

5. FAO 1974. Catches and Landings, 1973. Yb. Fish. Statist., 36.

6. GULLAND, J.A. 1974. The Management of Marine Fisheries. Scientechnica, Bristol.

7. MITCHELL, E. 1975. Porpoise, Dolphin and Small Whale Fisheries of the World, Status and Problems. IUCN Monograph No. 3.

8. SARIKAYA, S. 1975. Yunus baligi-dolfina. Ziraat Mühendisligi 104 30-36.

9. TOMILIN, A.G. 1957. Mammals of the USSR and Adjacent Countries, Vol. 9, Cetacea. Israel Program for Scientific Translations, Jerusalem, 1967.

10. TURKISH STATE INSTITUTE OF STATISTICS 1971. Su Ürunleri Anket Sonuçlari, 1969. Devlet Istatistik Enstitüsü, Ankara.

11. TURKISH STATE INSTITUTE OF STATISTICS 1974. Su Ürunleri Anket Sonuçlari, 1970-71. Devlet Istatistik Enstitüsü, Ankara.

Dr Fikret Berkes, Interdisciplinary Studies, Concordia University, Montreal, Canada

\section{Two Rare Sealions}

A report on the first year (1975) of a study of the Australian sealion Neophoca cinerea, which occurs only off the coast of South Australia, describes it as one of the rarer seals of the world, numbering perhaps 5000 animals, and says that the management of the remaining stocks requires close study. The report by John K. Ling and Gregory E. Walker, is published in the South Australian Naturalist. The study was started in response to a recommendation from the IUCN's Survival Commission (SSC) to the Australian and New Zealand Governments for a study and census of both this species and the New Zealand sealion $N$. hookeri, the population of which is also known to be low. The Australian sealion is believed to have been almost exterminated in the 19 th century by sealers for the sake of the oil.

\section{THE WILDLIFE RESEARCH CENTRE}

Middle Garland, Chulmleigh, Devon, England. Tel: Chulmleigh $\mathbf{4 6 1}$

JOHN HENSHAW, DR.TECHN. (Wildlife Management)

An International Service: Consultancy - Research - Management 